\title{
Leadership in the early years: Challenges and opportunities
}

\author{
Kate Thornton \\ School of Education, Victoria University Wellington, New Zealand
}

The lack of recognition and support for leadership and leadership development in the New Zealand early years' sector has long been recognised (Thornton, Wansbrough, Clarkin-Philips, Aitken, \& Tamati, 2009). This article reflects on what has changed in the 10 years since the publication of a discussion document by the Teachers Council which signalled a number of issues facing the sector with regard to leadership. Research and guiding documents are drawn on in order to identify the current challenges and opportunities, and recommendations are made for strengthening future leadership practice in the sector.

Keywords: leadership, early years, policy

\section{Introduction}

The year 2019 marks 10 years since the then Teachers Council published a discussion paper entitled Conceptualising leadership in early childhood education in Aotearoa New Zealand (Thornton, Wansbrough, Clarkin-Philips, Aitken, \& Tamati, 2009). This document explored the state of leadership and leadership development in the New Zealand early childhood education (ECE) sector at that time, discussed various issues and dilemmas facing the sector, and identified possible future directions. The following issues were highlighted: the low profile of leadership; the lack of an accepted definition or common understanding of leadership; confusion between leadership and management; concerns around newly qualified teachers taking on leadership roles; a lack of emphasis on leadership in the ECE sector by the Ministry of Education, particularly when compared with the support available for school leaders; and a lack of leadership development opportunities. So what, if anything, has changed over the past 10 years? This article will focus on the past and present contexts before discussing the progress that has been made since 2009, the challenges and opportunities facing leadership in the sector (currently referred to in Ministry of Education documents as early years rather than early childhood education) in 2019, and making recommendations and suggestions for strengthening future leadership practice.

\section{The context of the $\mathbf{2 0 0 9}$ discussion paper}

In the preface to the discussion paper Conceptualising Leadership in Early Childhood Education in Aotearoa New Zealand (Thornton et al., 2009), Peter Lind, then Director of the 
Teachers Council, explained that the document had resulted from the work of a think tank convened in $\mathbf{2 0 0 8}$ "to identify the issues around leadership in ECE and the present provision of leadership development opportunities" (p. iii). He clarified that this group had been formed because of the on-going responsibility of the Council "to provide professional leadership for the education sector" (p. iii) and the view of the Early Childhood Education Advisory Group that leadership in the ECE context was an issue worthy of attention. Different sections of the document outlined the current context, discussed conceptions of leadership in ECE and other settings, identified issues and dilemmas, and discussed characteristics of effective leadership development programmes.

The document highlighted the lack of attention that had been paid to leadership in the sector in the past. In 2009, the early childhood strategic plan, Pathways to the future: $\mathrm{Ng} \bar{a}$ huarahi arataki (Ministry of Education, 2002), was the only guiding document that referred to leadership, and that reference related to the provision of "leadership development programmes to strengthen leadership in ECE" (Ministry of Education, p. 15). This plan was abandoned at the end of 2008 during the writing of the discussion document following a change in government, and therefore there was no policy developed or targeted leadership development programme provided. Leadership was not mentioned specifically in the first edition of Te Whāriki, the early childhood curriculum document (Ministry of Education, 1996), although responsibilities in management, organisation, and practice were specified. Leadership was not focused on by the Education Review Office (ERO) to any great extent either; however, a 2008 report, The quality of assessment in early childhood education (ERO, 2008), did refer to "strong professional leadership" (p. 15) and "poor leadership" (p. 16) in relation to assessment practices. This was followed by the establishment of a link between effective leadership and quality ECE in the report, Quality in early childhood services (ERO, 2010).

\section{Leadership in the early years' sector in $\mathbf{2 0 1 9}$}

Before identifying the progress that has been made in recognising and strengthening leadership practice in the past 10 years, the current context in relation to the profile of leadership and leadership development will be described with reference to guiding documents. The revised Te Whäriki (Ministry of Education, 2018) includes a section in each of the strands entitled 'Considerations for leadership, organisation and practice'. These considerations appear to be focused on the pedagogical leadership practices of teachers/kaiako rather than those of professional or positional leaders, and Cooper (2019) has suggested that the text "reflects mixed messages about who might enact leadership and the nature of those leadership actions" (p. 34). The code of professional responsibility and standards for the teaching profession (Education Council, 2017) includes a standard entitled 'Professional relationships' which requires teachers to: "Establish and maintain professional relationships and behaviours focused on the learning and wellbeing of each learner" (p. 18). An elaboration of this standard sets out an expectation that teachers "Actively contribute, and work collegially, in the pursuit of improving my own and organisational practice, showing leadership, particularly in areas of responsibility" (p. 18). This document also appears to support the view that leadership is something expected of all teachers/kaiako. 
Other Ministry of Education documents such as Tãtaiako, cultural competencies for Māori learners (Ministry of Education, 2011) and Tapasā, a cultural competencies framework for teachers of Pacific learners (Ministry of Education, 2018) provide guidance on culturally responsive leadership competencies. These documents both have indicators for leadership practice which apply to leaders across the education sector. In contrast, while there are Professional Standards for principals (in secondary, primary and area schools), there are none for professional leaders in early years' settings. There has been, therefore, little specific guidance for positional leaders in the sector as to their roles and responsibilities.

Two recent programmes of work by the Teaching Council and by ERO have resulted in documents that have the potential to provide much needed guidance to leaders in the early years' sector. In 2018 (when the Council was still known as the Education Council), The leadership strategy for the teaching profession of Aotearoa New Zealand and the Educational leadership capability framework (Education Council, 2018b,a) were released. The vision of the strategy is:

To enable every teacher, regardless of their role or setting, to have the opportunity to develop their own leadership capability so that through principled and inspirational leadership, a culturally capable, competent and connected teaching profession achieves educational equity and excellence for all children and young people in Aotearoa New Zealand. (p. 4)

The strategy specifically refers to the historic lack of support for leadership development in the early years' sector, stating: "there is a need to address areas of leadership development that have been underserved, especially leaders in early childhood education" (p. 17). Both the strategy and framework identify the important role of the positional or professional leader as well as the expectation that all teachers/kaiako should be involved in leadership as suggested in the standards referred to earlier. The framework identifies nine educational leadership capabilities and examples of what these look like in different leadership spheres provided. The examples provided reflect the early years' sector as well as the school sector and publications from the early years' context are drawn on (see, for example, Davitt et al., 2017; Denee \& Thornton, 2017; Thornton \& Cherrington, 2014).

The revised Indicators of quality for early childhood education: what matters most (ERO), released in draft in September 2019, focuses much more strongly on leadership than the previous indicators, in particular the role of the positional leader and the development of professional learning communities. All of the revised five process indicators refer to the role of leaders and two, Whakangungu Ngaio: Collaborative professional learning builds knowledge and capability and Kaihautū: Leaders foster collaboration and improvement, specifically focus on leaders and leadership practices. While many of the outcomes refer to the role of leaders alongside that of teachers/kaiako, some are seen as the responsibility of those in leadership roles including the following:

- Leaders collaboratively develop and enact the service's philosophy, vision, goals and priorities, recognising Te Tiriti o Waitangi/ the Treaty of Waitangi as foundational;

- Leaders ensure access to opportunities for professional learning and development that builds capability; and

- Leaders develop, implement and evaluate the organisational systems, processes and practices that promote continuous improvement. (ERO, 2019, p. 12) 
Examples of practice are provided for each of these indicators, some of which will be referred to later in the article. These provide professional leaders with clear guidance on how to address the indicators and should be helpful to leaders wishing to reflect on their practice and make improvements to the learning and teaching in their settings.

At the time of writing, He taonga te tamaiti: Every child a taonga, the early learning action plan 2019-2029 (Ministry of Education, 2019a) had just been released. One of the five objectives in the plan is entitled 'Quality teaching and leadership' and the importance of leadership is briefly mentioned in the foreword along with teaching and governance. The plan promises some overdue support for leadership learning and development with the statement:

A national programme of PLD will also be designed to grow the leadership capability of teachers, kaiako and educators in leadership roles. The content of this will be informed by research evidence about effective leadership and the Teaching Council's Leadership Strategy for the teaching profession and Educational Leadership Capability Framework. (p. 26)

While it is pleasing to see some support for leadership PLD in the new plan, there seems to have been a missed opportunity to make leadership a stronger focus. Cooper (2019), in a recent article focusing on leadership development in relation to the draft strategic plan, suggested that leadership is inherent in the plan and signals that "leadership will be key to actualising the goals of the current strategic plan" (p. 34). It is disappointing that importance of leadership, recognised and promoted by ERO and the Teaching Council, is not more strongly acknowledged in this Ministry of Education document.

\section{What has changed?}

Reflecting on the six issues and dilemmas identified in 2009, it can be argued that progress has been made in some areas but not in others.

\section{The growing profile of leadership}

Leadership concepts and practices do appear to have a much higher profile in the early years' sector in 2019 than they did in 2009, and the increase in empirical research focusing on effective leadership practice in New Zealand ECE settings has recently been commented on (Clarkin-Phillips \& Morrison, 2018; Cooper, 2019). An example of this increase in research outputs is the focus of two special editions of the Journal of Educational Leadership, Policy and Practice on early years' leadership, one in 2011 and one in 2018. While much of the early research came from the Centres of Innovation programme (see, for example: Bary, et al., 2008; Meade, 2003; Te Kopae Piripono, 2006; Thornton, 2005), more recent research has canvassed a wider array of contexts such as: leadership of professional learning communities (Thornton \& Cherrington, 2014); distributed leadership for professional learning (Denee, 2017); democratic leadership (Dowling, 2017); emotional labour in leadership (Donald, 2018); and everyday collective leadership (Cooper, 2018).

The revised Indicators of quality for early childhood education: what matters most (ERO, 2019) emphasise the important role of both positional and distributed forms of leadership. This document not only clarifies the role of the positional leader in a wide range of areas but also signals the leadership responsibilities of all teachers/kaiako. Recent reports 
published by ERO have also commented on the importance of effective leadership practices. A report entitled 'Awareness and confidence to work with Te Whāriki' (ERO, 2018) highlights the importance of pedagogical leadership, suggesting "Pedagogical leaders need to have the capability to build kaiako knowledge and understanding of Te Whāriki and what it means for their intentional teaching practice" (p. 18). The important role professional leaders play in Pacific ECE contexts was highlighted in a 2015 ERO report, 'How do leaders support improvement in Pacific early childhood services?' This report, based on the reviews of eight Pacific services with good leadership practices, highlighted the importance of strong relationships and stewardship. The increase in leadership research and mentions of early years' leadership in guiding documents, particularly the quality indicators and the leadership strategy, can be seen as evidence of a higher profile.

\section{Coming to accepted definition or common understanding}

The lack of an accepted definition or common understanding of leadership was frequently referred to in early literature on leadership in the sector (see, for example: Ebbeck \& Waniganayake, 2003; Hard, 2004) and 10 years ago when the discussion document was published, there was no consensus on what leadership meant or looked like and a reluctance to identify with models of leadership in generic literature (Thornton, 2009). This lack of understanding of, and a lack of clarity around who should be involved in practising leadership contributed to confusion among New Zealand teachers/kaiako and leaders about the concept of leadership. The lack of professional standards for leaders in the early years sector could be seen to have added to this lack of clarity.

While the concept of distributed leadership was being used at the time of the publication of the discussion document, it was not well known or understood by those in the sector and the focus on distributed leadership in much of the literature over the past 10 years has provided teachers with a concept they can identify with (Clarkin-Phillips \& Morrison, 2018). A number of New Zealand studies have explored aspects of leadership distributed across members of the learning community (see for example: Clarkin-Phillips, 2011; Cooper 2018; Denee, 2017) and as mentioned above, this approach to leadership is promoted in guiding documents such as Te Whāriki, the professional standards, the leadership strategy and revised quality indicators. While distributed leadership is also recommended in international studies (Colmer, Waniganayake, \& Field, 2015), effective implementation is not often seen (Heikka \& Hujala, 2013). It is also important to point out that some of the international literature is not directly relevant to the New Zealand early years' sector due to the higher level of qualification of most New Zealand teachers/kaiako and the use of untrained assistants in contexts such as Scandinavia where much of the research is situated.

A useful definition of leadership is provided in the leadership strategy:

Educational leadership is the practice of supporting others to make a positive difference to children's and young people's learning. It involves creating and sustaining the conditions known to enhance their learning. It requires the capability to work effectively with colleagues and other adults to support learning and to create new solutions and knowledge together. For those in positional leadership roles it also involves building and sustaining thriving teams and institutions that support ongoing professional learning. (Education Council, 2018b, p. 8) 
This definition, which is also quoted in the revised Indicators of quality for early childhood education: what matters most (ERO, 2019), acknowledges both the expectation that all teachers/kaiako should be involved in leadership, thereby supporting distributed leadership while recognising the important role of positional leaders. Denee (2017) found that for the potential of distributed leadership to be realised, professional leaders need to establish shared understanding of leadership concepts and practices and this definition would make a useful starting point for these conversations and help teachers/kaiako come to a common understanding of what leadership is and how it can be practised.

\section{Leadership vs management}

It would be expected that the higher profile and clearer understanding of the concept of leadership would mean that the difference between leadership and management is better understood now than in 2009. Klevering and McNae (2018), reporting on a recent study of New Zealand early childhood leaders' interpretations of leadership and enactment of leadership practice, have, however, warned that that there is still some confusion between the terms. These authors suggest that there is sometimes a focus on management at the expense of educational leadership in the private sector. Leaders in their study believed that privatisation resulted in inadequate staffing levels and high child:adult ratios leading to teachers feeling stressed and leaders feeling that management took priority over leadership. Klevering and McNae suggest that both leadership and management are important and that learning opportunities for both be prioritised.

The terminology used when describing those in formal leadership roles in New Zealand early years' settings continues to vary between services and may contribute to continuing confusion. While in kindergartens, formal leaders are referred to as head teachers or senior teachers, titles that can be seen to denote a focus on educational leadership, in many education and care services, including private centres, the term manager is used. This term can be seen to emphasise the management rather than leadership focus of the role and may underplay the leadership capabilities required. The revised Indicators of quality for early childhood education: what matters most (ERO, 2019) have separate sections focusing on leadership and on governance and management (Whakaruruhau: Stewardship through effective governance and management, ERO, 2019), demonstrating recognition of these different roles, particularly in corporate settings.

\section{Newly qualified teachers taking on leadership roles}

There appear to be no data available on the age and experience of those teachers/kaiako in professional leadership roles, therefore it is difficult to know whether newly qualified teachers are still taking on leadership roles in significant numbers. If they are, they are likely to find themselves lacking knowledge about effective leadership practice or support for their roles. The shortage of qualified teachers overall has been the focus of recent media attention. Johnson (2018) reported in the New Zealand Herald that early childhood services were facing their worst-ever teacher shortage, and that an Early Childhood Council survey found 30 per cent of childcare centres had vacancies for qualified teachers. A 2018 press release from the New Zealand Education Institute: Te Riu Roa (NZEI) noted that 800 new early childhood teachers were needed to replace those leaving the profession, and 1300 more teachers were needed to meet growth in demand for ECE places (NZEI, 2018). This shortage has recently been acknowledged by the Ministry of Education through the release of an ECE Teacher 
Supply Package (Ministry of Education, 2019b). Given the shortage of qualified teachers/kaiako, it would seem probable that there may be a shortage of candidates for leadership roles, particularly in areas of growth.

\section{Ongoing lack of emphasis on leadership in the sector by the Ministry of Education}

Up until very recently there has been no significant change in the Ministry of Education's engagement with the issue of leadership in the early years despite the greater emphasis by the Teaching Council and ERO. In personal communication, Ministry personnel have in the past used the argument that the Ministry is not required to offer the support provided for leadership in schools to early years' services because they are not part of the compulsory sector. It has also been suggested that the Ministry is reluctant to fund programmes that will be accessible for profit as well as non-profit services (Klevering \& McNae, 2018). Leadership in the sector has recently been described as "largely devoid of policy direction and resourcing initiatives" (Clarkin-Phillips \& Morrison, 2018, p. 1). This is despite an Advisory Group on Early Learning, commissioned by the Ministry of Education, recommending a major professional development initiative for the sector with a focus on leadership for learning over four years (Advisory Group on Early Learning, 2015). The only funding since the release of the discussion document in $\mathbf{2 0 0 9}$ seems to have been for the provision of limited PLD contracts focused on pedagogical leadership and some online resources. While the quality and quantity of online resources related to leadership has increased as a result of the release of the revised $T e$ Whāriki, those in professional leadership roles have had limited incentive or support to develop their leadership capabilities, particularly when compared to the support provided for school principals (Thornton, 2015).

While the recently released plan holds some promise for supporting leadership PLD, the opportunity to acknowledge the link between quality and leadership has been missed. The section in the plan on the quality of provision does not mention leadership, suggesting that there is not a significant shift in the thinking within the Ministry of Education about the importance of leadership and the link between leadership and quality in the early years' sector. Until this happens, it will remain a poor relation when compared with the schooling sector.

\section{Ongoing lack of leadership development opportunities}

The lack of leadership learning and development opportunities for professional leaders mentioned above has been commented on in a range of literature over the past 10 years (see for example, Cooper, 2014, 2019; Denee, 2017; Klevering \& McNae, 2018; Thornton, 2005, $2009,2015)$. It seems that the importance of early years' leadership is recognised by the Teaching Council and ERO and there is recognition of the need for leadership PLD in the new 10 -year plan. The wording in the plan that the PLD content of this will be "informed by research evidence about effective leadership and the Teaching Council's Leadership Strategy for the teaching profession and Educational Leadership Capability Framework (2018)" (Ministry of Education, 2019a, p. 26) is welcome. The approaches to strengthen leadership outlined in The leadership strategy for the teaching profession of Aotearoa New Zealand (Education Council, 2018b), which include professional learning groups and a variety of blended learning opportunities, reflect the approaches suggested in the Teachers Council 2009 discussion paper such as encouraging distributed leadership approaches and reflective practice, and providing support through mentoring and networking. 


\section{Current challenges}

While some progress has been made to strengthen leadership practice in the New Zealand early years' sector, there are still several challenges. It is too soon to tell what the promised national programme of PLD designed to grow the leadership capability of those in leadership roles recently announced in the 10-year action plan (Ministry of Education, 2019a) will look like and how widespread it will be. The establishment of a Leadership Centre within the Teaching Council that will be inclusive of early years has recently been announced as part of the Tomorrow's School reform; however, the Ministry of Education will retain responsibility for setting criteria for leadership roles and for providing the associated PLD. It is yet to be seen how these bodies will work together effectively to provide this much needed support.

Another challenge is the lack of strong professional networks focused on leadership policy and practice. While school principals work together in organisations such as the New Zealand Principals' Federation and the Secondary Principals' Association of New Zealand, there are no equivalent bodies for professional leaders in the early years' sector and no strong collective voice lobbying for leadership-related resourcing. Some early years' services belong to Kāhui Ako, communities of learning, and the new 10-year plan supports ongoing involvement; there is, however, little evidence of the impact of this participation on strengthening leadership as the focus of evaluation has been on the participation of those in the schooling rather than in the early years' sector.

\section{Current opportunities}

Alongside these challenges there are a number of potential opportunities. The revised Te Wharriki (Ministry of Education, 2018), the Standards for the teaching profession (Education Council, 2017), the revised Indicators of quality for early childhood education: what matters most (ERO, 2019), The leadership strategy for the teaching profession of Aotearoa New Zealand and the Educational leadership capability framework (Education Council, 2018a,b) support the notion of distributed leadership and provide teachers/kaiako with opportunities to see how they can be involved in leadership. The new 10-year plan (Ministry of Education, 2019a) offers promise for some much needed PLD while missing an opportunity to recognise the significance of effective leadership practice. The Teaching Council's leadership strategy acknowledges that leaders in early childhood settings are a priority group for PLD (Education Council, 2018b) and the capability framework offers opportunities for strengthening leadership practice for all those involved in leadership practice.

Of these opportunities, the revised quality indicators provide perhaps the greatest potential for strengthening leadership practice in the sector given their explicit focus on the role of leadership in positively impacting on outcomes for children and the fact that ERO will be using these to evaluate the performance of services and encourage improvement (ERO, 2019). By making leadership practice explicit, they provide guidance on how leaders can ensure their practices "focus on what matters most in the provision of high-quality early childhood education in the unique context of Aotearoa New Zealand" (ERO, p. 4). Specific examples drawn from the indicators will be referred to in the following sections. 


\section{Strategies for strengthening leadership practice}

At the time of writing, it is unknown what future funded support there will be for leadership learning and development in the early years' sector. There are, however, ways in which both positional leaders and teachers/kaiako can build their personal and collective leadership capabilities, including sharing leadership responsibilities, building professional learning communities, engaging in mentoring and coaching, and building strong networks. The revised quality indicators and leadership capability framework are useful tools for reflecting on what capabilities need to be developed and these and the leadership strategy will be referred to in the following discussion along with current research.

\section{Distributed leadership}

Teachers/kaiako generally and professional leaders in particular should be encouraged to reflect on how leadership is shared or distributed in their settings. Recent research, such as that by Denee (2017) and Cooper (2019), provides useful guidance for leaders on how to effectively strengthen leadership practice in others. Denee drew on a survey of the New Zealand early years' sector to explore perceptions of distributed leadership practice and professional learning as well as case studies of three highly effective ECE services to understand the ways that distributed leadership can be enacted. Her study found that professional leaders encouraged distributed leadership through: mentoring and coaching; fostering relational trust; and creating vision and designing supportive structures. Similarities between the teams and professional leaders interviewed in her study highlighted commonalities in the professional leaders' approaches despite their different contexts. Effective professional leaders established relational trust as a foundation for distributed leadership, and utilised mentoring and coaching strategies to develop their team, while providing oversight and vision.

Cooper's (2018) study, exploring leadership in two infant and toddler teaching teams within one high-quality early childhood education and care centre, focused on collective teacher leadership practice rather than the leadership of those in formal roles. She found that leadership took the form of "intentional and sustained, object-driven activity reliant on whole-team inquiry, relational dialogue, and relational agency-in-flow (p. ii). Cooper's research found that in order for everyday collective leadership to be enacted, teachers needed opportunities to engage in meaningful dialogue, to discuss goals and practices, and to consider their own leadership practice. They also needed their professional leaders to share power with them, promote values-based norms, and encourage the exploration of the congruence between espoused and lived values. Both Denee's and Cooper's studies involved exploring distributed leadership practices in high-quality services and both provide useful guidance for teachers/kaiako and professional leaders. The importance of teachers/kaiako having opportunities to discuss and reflect on their understandings and enactment of leadership was highlighted in both studies as was the support of professional leaders who encouraged such leadership opportunities through sharing responsibility. Sharing responsibility is one of the four responsibilities in the Te Kōpae Piripono framework and denotes an interaction and engagement with others, being able to listen to others' points of 
view, acknowledging different perspectives and both asking for and providing assistance (Te Kōpae Piripono, 2006).

The crucial role of the professional leader in developing distributed leadership has been commented on in the literature (Colmer et al., 2015; Denee \& Thornton, 2017; Thornton, 2005). These authors suggest that professional leadership is complemented by allowing different members of the community to enact leadership. Colmer et al. argue that in the ECE context, "Distribution does not replace professional leadership structures, and site leaders play an important role in coordinating leadership and developing leadership capability within the group" (p. 104). Thornton (2005) suggested that positional leaders have a significant influence: "Leaders who promote and model respectful and collaborative relationships, and provide support and mentoring, encourage their colleagues to become involved in the leadership of the centre" (p. 161). Several aspects of the professional leader's role are recurrent in distributed leadership literature: maintaining vision and a learning focus; offering teachers opportunities for leadership; developing relational trust (Denee \& Thornton); and managing supportive structures (Colmer et al., 2015). Thornton's study found that leaders who had opportunities to learn about the theory and practice of leadership adopted more collaborative leadership practices leading to a distributed leadership approach (Thornton, 2009).

As mentioned above, distributed leadership is promoted throughout the leadership strategy (see the vision statement above) and in the professional standards and revised Te Whāriki. Distributed leadership is referred to in the explanation of the process outcome Kaihautū: Leaders foster collaboration and improvement, with the importance of leadership roles being open to teachers/kaiako, parents, whānau and children as well as those in positional leadership roles (ERO, 2019). Encouraging leadership in others is signalled in the capability Building and sustaining collective leadership and professional community with one of the indicators for those leading organisations being "considering opportunities and support given to staff to grow their capabilities in leadership" (Education Council, 2018a, p. 9).

\section{Professional learning communities}

The model of professional learning communities has been suggested as a useful framework for reflecting on the way shared and supported leadership, collective learning, shared personal practice and supportive relationships are enacted in early years' services (Thornton, 2015). Professional learning communities have been described as "an inclusive and mutually supportive group of people with a collaborative, reflective and growth-oriented approach towards investigating and learning more about their practice in order to improve pupils' learning" (Stoll, 2011, p. 104). Distributed leadership is inherent in a professional learning community model, although the professional leader also has a crucial role in ensuring the community's effectiveness. Findings from a case study exploring factors contributing to effective professional learning communities in the New Zealand early years' sector (Thornton \& Cherrington, 2014) highlighted the importance of the support of the professional leader. This support was necessary for the effective functioning of the professional learning communities and for any shifts in practice to become embedded. Leadership was, however, distributed to some extent with teachers taking leadership roles related to their knowledge and expertise. This research study is referred to in the capability framework (Education Council, 2018a). 
Leadership practice was considered in a more recent study exploring factors influencing the sustainability of professional learning communities in ECE over a $2 \frac{1}{2}$ year period (Thornton \& Cherrington, 2019). Two different professional learning communities were researched and the differences between the models and approaches analysed to reveal what factors were influential in developing and supporting their sustainability. The important role of the professional leader in influencing the conditions under which the professional learning community operates and encouraging others to become involved in leadership was acknowledged. While professional leaders in this study demonstrated awareness of involving others, not all teachers felt empowered to practise leadership. This may have been because the distribution of leadership, characteristic of professional learning communities, was not sufficiently deconstructed with participants in order to provide clarity. While most of the literature relates to professional learning communities within services, building trusting and collaborative learning communities between services is also important and such networking will be discussed below.

While the term professional learning community is not used in the leadership strategy or capability framework, many of the capabilities and actions resonate with the concept. For example, the explanation of the capability Building and sustaining collective leadership and professional community states:

Effective learning happens when the teachers responsible for it work together to share their knowledge and inquire into their practice. Leadership attends to the conditions and practices that are needed for this to occur, enhancing a strong sense of an engaging, active, and achieving community that sees itself involved in ongoing learning, innovation and improvement for the benefit of each and all of its learners. (Education Council, 2018a, p. 5)

Professional learning communities are specifically referred to in the revised Indicators of quality for early childhood education: what matters most (ERO, 2019). Whakangungu Ngaio: Collaborative professional learning builds knowledge and capability process outcome states "Children's learning is enhanced through leaders and kaiako working as a professional learning community" (ERO, 2019, p. 19) and characteristics of effective professional learning opportunities such as the use of evidence, goal setting, and sharing practice are outlined.

\section{Mentoring, coaching and critical friendships}

The importance of mentoring and coaching in supporting leadership learning has been emphasised (see, for example: Garvey, Stokes, \& Megginson, 2018; Gray, Garvey, \& Lane, 2016). In the early years sector, mentoring for leaders has been promoted by Waniganayake, Cheeseman, Fenech, Hadley, and Cheeseman (2012) who suggest that it benefits experienced as well as new leaders as mentors who can act as sounding boards and critical friends. Similarly, Rodd (2013) suggests that both mentoring and coaching can support the professional learning of both individuals and teams. Effective mentoring and coaching relationships, according to Rodd, should be supportive and non-judgmental and underpinned by honesty, trust, and mutual respect. Effective leaders in Denee's (2017) research mentored their teams and demonstrated that mentoring and coaching others can be an effective leadership practice as well as a way of developing leaders and leadership.

Mentoring and coaching teachers/kaiako is an example of effective leadership practice in relation to the indicator "leaders ensure access to opportunities for professional 
learning and development that builds capability" (ERO, 2019, p. 26) within Kaihautū: Leaders foster collaboration and improvement. While the educational leadership capability framework does not specifically mention mentoring and coaching, supporting staff to develop their leadership capabilities (Education Council, 2018a) could be seen as involving mentoring and coaching. Critical friends are referred to in the capability of Attending to their own learning and leaders and their own wellbeing with the indicators including "uses critical friends to discuss their own leadership practice and extend their knowledge and capabilities" (Education Council, p. 10). A critical friend, defined by Costa and Kallick (1993) as a "trusted person who asks provocative questions, provides data to be examined through another lens, and offers critique of a person's work as a friend" (p. 50) may come within or outside of an educational setting. Peers acting as critical friends in a school setting have been the focus of a study (Wennergren, 2016), and Stoll (2011) has discussed the role of importance of critical friends from both within and without in the context of professional learning communities. Cherrington and Thornton (2014) took the role of critical friends as well as researchers and facilitators when working with teachers in a professional learning community study. Questioning and exposing teachers to different ways of thinking are potential benefits of critical friends from outside of the service (Thornton \& Cherrington, 2019).

\section{Building strong networks}

The current lack of strong professional networks focused on leadership has been noted above and these would help strengthen leadership policy and practice in the sector. Online networks appear to be working well for principals and while various networks for teachers/kaiako in the early years exist, none are focused specifically on leadership. A recently published paper Sustaining system-wide change: Investing in leadership and building leadership capacity (Baker, 2019), which draws on the thinking and evidence informing the leadership strategy, emphasises the importance of engaging actively in both regional and local networks. Baker promotes the potential of networks to draw on leadership wisdom in order to strengthen the education system as a whole and contribute to more equitable learning opportunities for children and young people.

The importance of networking across services is recognised in the draft ERO quality indicators both in relation to Whakangungu Ngaio: Collaborative professional learning builds knowledge and capability and Kaihautū: Leaders foster collaboration and improvement (ERO, 2019). One of the examples of effective practice for the indicator related to working as a professional learning community refers to seeking "opportunities to share their professional knowledge, expertise and practice in their wider professional community" (p. 19). Another relevant example of practice is engaging in "effective inter-professional work with others who support the health, wellbeing and learning of children and their whānau" (p. 19), an example of practice relating to the process indicator "Relational trust enables collaboration and sustained improvement" (p. 26) from Kaihautū: Leaders foster collaboration and improvement.

Networking is a strong focus of The leadership strategy for the teaching profession of Aotearoa New Zealand (Education Council, 2018b), because of the opportunities for the sharing of knowledge and practice that professional networking events provide. One of the success indicators in the strategy is "Leaders can easily find and participate in a range of networks (including digital networks) that are relevant to their leadership learning needs and 
goals." (p. 21). The description of the capability of Contributing to the development and wellbeing of education beyond their organisation suggests that:

Leaders bring their knowledge and experience of making improvements to local and national professional networks, as well as exploring opportunities to work with other educational organisations, local communities, government agencies and others to develop and improve educational provision and policy. (Education Council, 2018a, p. 7)

The leadership strategy acknowledges the need for leaders "to act as system and community leaders" (Education Council, 2018b, p. 19) and the capability framework refers to using "networks beyond the organisation" (p. 10) and playing "an active role in leader networks within the spirit of ako" (p. 11). The 10-year plan also highlights the importance of "crossservice and cross-sector collaboration" (Ministry of Education, 2019a, p. 41). A challenge for those working in the early years' sector is to work collaboratively across settings and where possible across sectors to influence leadership policy and practice.

\section{Conclusion}

Some progress has been made over the past 10 years in that leadership in the early years' sector has a higher profile, there is greater understanding of what is involved in leadership practice and there is more relevant research to draw on. While there are promises that some resourcing for leadership PLD is to be made available, this has yet to be realised. There are opportunities available to both professional leaders and teachers/kaiako for strengthening leadership in the sector, including drawing on guiding documents, in particular the revised ERO quality indicators and the leadership strategy and capability framework which all provide teachers/kaiako with opportunities to see how they can be involved in leadership. The explicit references to effective leadership practice throughout the revised quality indicators could prove to be the most important lever for change given that all services will be required to engage with these as part of their internal evaluation processes. Professional leaders and teachers/kaiako can draw on these documents in building their personal and collective leadership capabilities, including by sharing leadership responsibilities, building professional learning communities, engaging in mentoring and coaching, and building strong networks. It is to be hoped that in another 10 years' time, the conversation will have changed and leadership in the early years will be given the recognition and resourcing it deserves.

\section{References}

Advisory Group on Early Learning. (2015). Report of the advisory group on early learning. Wellington: Ministry of Education.

Baker, R. (2019). Sustaining system-wide change: Investing in leadership and building leadership capacity. Melbourne: Centre for Strategic Education.

Bary, R., Deans, C., Charlton, M., Hullet, H., Martin, F., Martin, L., ... Scrivens, C. (2008). Ako ngatahi teaching and learning together as one: From leadership to enquiry: Teachers' work in an infants' and toddlers' centre. Wellington: Ministry of Education. 
Clarkin-Phillips, J. (2011). Distributed leadership: Growing strong communities of practice in early childhood centres. Journal of Educational Leadership, Policy and Practice, 26(2), 14-25.

Clarkin-Phillips, J., \& Morrison, M. (2018). Journal of Educational Leadership, Policy and Practice, 33(1), 1-4.

Colmer, K., Waniganayake, M., \& Field, L. (2015). Implementing curriculum reform: Insights into how Australian early childhood directors view professional development and learning. Professional Development in Education, 41(2), 203-221.

Cooper, M. (2014). 'Everyday teacher leadership': A reconceptualisation for early childhood education. Journal of Educational Leadership, Policy and Practice, 29(2), 84-96.

Cooper, M. (2018). Shifting the lens: Everyday collective leadership activities in education (Doctoral thesis). University of Auckland, New Zealand.

Cooper, M. (2019). Addressing leadership development in ECE: A response to the Strategic Plan for Early Learning 2019-29. Early Childhood Folio, 23(1), 33-36.

Costa, A., \& Kallick, B. (1993). Through the lens of a critical friend. Educational Leadership, 51(2), 49-51.

Davitt, G., Carroll-Lind, J., Ryder, D., Smorti, S., Higginson, R., \& Smith, M. (2017). Poutoko whakatipu poutoko: Whakamanahia ngā poutoko kōhungahunga hei hautūtang a toitū: Leaders growing leaders: Effective early childhood leaders for sustainable leadership: Case studies. Wellington, New Zealand: Te Rito Maioha Early Childhood New Zealand \& Ako Aotearoa National Centre for Tertiary Excellence.

Denee, R. (2017). Distributed leadership for professional learning: Effective leadership for professional learning and distributed leadership (MEd thesis). Victoria University of Wellington, New Zealand.

Denee, R., \& Thornton, K. (2017). Effective leadership practices leading to distributed leadership. Journal of Educational Leadership, Policy and Practice, 32(2), 33-45.

Donald, N. (2018). "Held together and happy": Unmasking experiences of emotional labour in early childhood leadership (Master's diss.). Auckland: University of Auckland, New Zealand.

Dowling, L. (2017). Democratic leadership: A local story (Master's thesis). University of Waikato, Hamilton, New Zealand.

Ebbeck, M., \& Waniganayake, M. (2003). Early childhood professionals: Leading today and tomorrow. Sydney: Maclennan \& Petty.

Education Council. (2017). The code of professional responsibility and standards for the teaching profession. Wellington: Ministry of Education.

Education Council. (2018a). Educational leadership capability framework. Wellington: Ministry of Education.

Education Council. (2018b). The leadership strategy for the teaching profession of Aotearoa New Zealand. Wellington: Ministry of Education.

Education Review Office. (2008). The quality of assessments in early childhood education. Wellington, New Zealand: Ministry of Education.

Education Review Office. (2010). Quality in early childhood services. Wellington, New Zealand: Ministry of Education.

Education Review Office. (2015). How do leaders support improvement in Pacific early childhood services? Wellington, New Zealand: Ministry of Education. 
Education Review Office. (2018). Awareness and confidence to work with Te Whāriki. Wellington, New Zealand: Ministry of Education.

Education Review Office. (2019). Indicators of quality for early childhood education: What matters most (draft). Wellington. New Zealand: Ministry of Education.

Garvey, B., Stokes, P., \& Megginson, D. (2018). Coaching and mentoring: Theory and practice (pp. 47-64). London: Sage.

Gray, D., Garvey, B., \& Lane, D. (2016). A critical introduction to coaching and mentoring (pp. 164-178). London: Sage.

Hard, L. (2004). How leadership is understood in early childhood education and care. Journal of Australian Research in Early Childhood Education, 11(1), 123-131.

Heikka, J., \& Hujala, E. (2013). Early childhood leadership through the lens of distributed leadership. European Early Childhood Education Research Journal, 21(4), 568-580.

Johnson, S. (2018, 29 October). Early childhood teacher shortage means teachers can get 'whatever they want'. New Zealand Herald.

Klevering, N., \& McNae, R. (2018). Making sense of leadership in early childhood education: Tensions and complexities between concepts and practices. Journal of Educational Leadership, Policy and Practice, 33(1), 5-17.

Meade, A. (2003). ECE Centres of Innovation. Paper presented at the Leadership and Management in the Early Years conference, Pen Green Leadership Centre, Corby, UK.

Ministry of Education. (1996). Te Whāriki: He whāriki matauranga mō ngā mokopuna o Aotearoa: Early childhood curriculum. Wellington, New Zealand: Learning Media.

Ministry of Education. (2002). Pathways to the future: Ngā huarahi arataki: A 10-year strategic plan for early childhood education. Wellington: Learning Media.

Ministry of Education. (2011). Tãtaiako: Cultural competencies for Māori learners. Wellington, New Zealand: Author.

Ministry of Education. (2017). Te Whāriki: He whāriki matauranga mō ngā mokopuna o Aotearoa: Early childhood curriculum. Wellington, New Zealand: Author.

Ministry of Education. (2018). Tapasā: A cultural competencies framework for teachers of Pacific learners. Wellington, New Zealand: Author.

Ministry of Education. (2019a). He taonga te tamaiti: Every child a taonga: The early learning action plan 2019-2029. Wellington, New Zealand: Author.

Ministry of Education. (2019b). He Pānui a Kōhunghunga. Retrieved from https://mailchi.mp/education/he-pnui-khungahunga-the-early-learning-bulletinseptember-2019-special-edition

Ministry of Education. (2019c). He taonga te tamaiti: Every child a taonga: Strategic plan for early learning 2019-29-Draft for consultation. Wellington: Author.

Ministry of Education. (2019d). Supporting all schools to succeed: Reform of the tomorrow's schools system. Retrieved from https://conversation.education.govt.nz/assets/ TSR/November-2019/TSR-Government-Response-WEB.pdf

NZEI. (2018). Early childhood teacher shortage severe. Retrieved from https://www.nzei.org.nz/NZEI/Media/Releases/2018/10/Early_childhood_teacher_s hortage_severe.aspx

Rodd, J. (2013). Leadership in early childhood (4 ${ }^{\text {th }}$ ed.). Sydney, Australia: Allen \& Unwin. Stoll, L. (2011). Leading professional learning communities. In J. Robertson \& H. Timperley (Eds.), Leadership and learning (pp. 103-117). London: Sage. 
Te Kōpae Piripono. (2006). Ngā takohanga e wha: The four responsibilities. Retrieved from http://www.lead.ece.govt.nz/CentresOfInnovation/COIDocsAndResources/SrvcSpeci ficDocsAndResources/NgāTakohangaeWhaTheFourResponsibilities.htm.

Thornton, K. (2005). Courage, commitment and collaboration: Notions of leadership in the New Zealand ECE 'Centres of Innovation' (Master's thesis). Victoria University of Wellington, New Zealand.

Thornton, K. (2009). Blended action learning: Supporting leadership learning in the New Zealand early childhood education sector (PhD thesis). Victoria University of Wellington, New Zealand.

Thornton, K. (2015). The impact of mentoring on leadership capacity and professional learning. In C. Murphy \& K. Thornton (Eds.), Mentoring in early childhood education: A compilation of thinking, pedagogy and practice (pp. 1-13). Wellington, New Zealand: NZCER Press.

Thornton, K., \& Cherrington, C. (2014). Leadership in professional learning communities. Australasian Journal of Early Childhood, 39(3), 94-102.

Thornton, K., \& Cherrington, S. (2019). Professional learning communities in ECE: A vehicle for professional growth. Professional Development in Education, 45(3), 418-432.

Thornton, K., Wansbrough, D., Clarkin-Phillips, J., Aitken, H., \& Tamati, A. (2009). Conceptualising leadership in early childhood education in Aotearoa New Zealand. Wellington, New Zealand: New Zealand Teachers Council.

Waniganayake, M., Cheeseman, S., Fenech, M., Hadley, F., \& Cheeseman, W. (2012). Leadership: Context and complexities in early childhood education. Melbourne: Open University Press.

Wennergren, A. (2016). Teachers as learners: With a little help from a critical friend. Education Action Research, 24(2), 260-279.

Dr Kate Thornton is an associate professor in the School of Education at Victoria University of Wellington. Her research is focused on educational leadership and leadership development, mentoring and coaching, and professional learning communities. Kate was a member of the Education Review Office Academic Expert's Group in 2018 advising the Education Review Office on revising the indicators used to review the quality of New Zealand ECE services and of New Zealand Education Council's Academic Reference Group advising on the draft leadership strategy in 2017.

Email: kate.thornton@vuw.ac.nz

ORCID: http://orcid.org/0000-0001-7785-0204 